\title{
Diagnosis and pharmacological management of small intestinal bacterial overgrowth in children with intestinal failure
}

\author{
Bushra A Malik MSc, Yuan Y Xie MD, Eytan Wine MD PhD, Hien Q Huynh MBBS FRACP
}

BA Malik, YY Xie, E Wine, HQ Huynh. Diagnosis and pharmacological management of small intestinal bacterial overgrowth in children with intestinal failure. Can J Gastroenterol 2011;25(1):41-45.

The present article provides a general overview of the possible diagnostic procedures available for the management of small intestinal bacterial overgrowth in pediatric patients with intestinal failure. The focus is to address current diagnostic tools and understand their associated advantages and disadvantages based on a literature search. Culture of small intestinal aspirates, noninvasive breath tests and an emerging interest in quantitative bacterial DNA fingerprinting are discussed. Proper management is critical for preventing the recurrence of small intestinal bacterial overgrowth and its related complications. Antibiotic prophylaxis is one approach to the treatment of bacterial overgrowth in intestinal failure patients. Although treatment trials can be challenging in such a vulnerable population, more investigative clinical studies examining early diagnosis, more effective control of recurrence and the prevention of associated complications must be conducted.

Key Words: Antibiotics; Hydrogen breath test; Intestinal failure; Pediatrics; Small bowel culture; Small intestinal bacterial overgrowth

mall intestinal (bowel) bacterial overgrowth (SIBO) is a clin$\checkmark$ ical problem associated with abnormally high bacterial counts in the small intestine that are associated with clinical features. The presence of more than $10^{5}$ colony-forming units $/ \mathrm{mL}$ of colonic-type (eg, Gram-negative strains, strict anaerobes and enterococci) counts from intestinal aspirate is considered to be diagnostic of bacterial overgrowth (1). This increase is believed to be the result of excess numbers of Gram-negative aerobes and, especially anaerobes, migrating from the lumen of the large bowel to the small bowel. Abnormal concentrations of bacteria in the small bowel often leads to malabsorption due to inadequate micellar formation and exacerbation of mucosal injury resulting in increased intestinal permeability (2).

Little has been published on SIBO in children with intestinal failure (IF). For the present review, a comprehensive literature search from 1966 to present was performed using PubMed, and from 1990 to present using 'Google Scholar'. The following search phrases were used: "paediatric small bowel bacterial overgrowth", "paediatric intestinal failure", "intestinal bacterial overgrowth", "diagnosis for bacterial overgrowth", "hydrogen breath test for bacterial overgrowth" and "antibiotics for bacterial overgrowth". The reference lists of the selected articles were also searched for additional references. An evaluation of 97 potential articles (and their abstracts) yielded only 52 full
Le diagnostic et la prise en charge pharmacologique de la prolifération bactérienne dans l'intestin grêle chez des enfants une insuffisance intestinale

Le présent article donne un aperçu général des techniques diagnostiques possibles pour prendre en charge la prolifération bactérienne dans l'intestin grêle chez des patients pédiatriques ayant une insuffisance intestinale. Les auteurs s'intéressent aux outils diagnostiques courants et à comprendre leurs avantages et désavantages d'après une analyse bibliographique. Ils abordent la culture des aspirats de l'intestin grêle, les épreuves respiratoires non effractives et l'intérêt émergent pour l'empreinte génétique quantitative des bactéries. Une prise en charge convenable est essentielle pour prévenir la récurrence de prolifération bactérienne dans l'intestin grêle et ses complications connexes. La prophylaxie antibiotique fait partie des interventions thérapeutiques de la prolifération bactérienne chez les personnes ayant une insuffisance intestinale. Même si les essais thérapeutiques peuvent être difficiles à exécuter auprès d'une population si vulnérable, il faut tenir plus d'essais cliniques exploratoires sur le diagnostic précoce, assurer un contrôle plus efficace des récurrences et prévenir les complications connexes.

articles that met the inclusion criteria for the present review. Although articles focusing on pediatric care were favoured, papers reporting on adult subjects were also reviewed.

Children with IF are at high risk for developing SIBO because of impaired intestinal motility (due to stasis) and/or short bowel syndrome. Additional factors and predisposing conditions for SIBO in IF patients are outlined in Table 1. Children may appear malnourished, show symptoms of vomiting, diarrhea, abdominal distension and, in some cases, may develop metabolic acidosis from the accumulation of D-lactate, a byproduct of bacterial fermentation of carbohydrates (3). However, SIBO symptoms may be masked by manifestations of underlying gastrointestinal tract diseases in these patients. SIBO may also increase the risk of catheter-related sepsis and exacerbate IF-associated liver disease in this parenteral nutrition-dependent population (4-6) because $40 \%$ to $60 \%$ of cases involving infants on long-term parenteral nutrition develop liver disease secondary to IF (3). $\mathrm{SIBO}$ and its complications may delay or prevent weaning these patients off total parenteral nutrition, thus contributing to the progression of their liver disease (7).

Increased intestinal permeability and impaired host immune defence are believed to be the primary mechanisms promoting the translocation of bacteria and their byproducts across the epithelial tract (7). This, in turn, increases the risk of sepsis,

Division of Pediatric Gastroenterology and Nutrition, Department of Pediatrics, Stollery Children's Hospital, Department of Medicine,

University of Alberta, Edmonton, Alberta

Correspondence: Dr Hien Q Huynh, Department of Pediatrics, Stollery Children's Hospital/University of Alberta, Aberhart Centre \# 1,

Room 9219, 11402 University Avenue Northwest, Edmonton, Alberta T6G 2J3. Telephone 780-407-3339, fax 780-407-3507,

e-mail hien.huynh@ualberta.ca

Received for publication August 10, 2009. Accepted July 16, 2010 
TABLE 1

Clinical conditions predisposing to small intestinal bacterial overgrowth in patients with intestinal failure

Hypochlorhydria (induced by $\mathrm{H}_{2}$-receptor antagonists or proton pump inhibitors)

Ostomies (potential for bacterial ingress)

Immunodeficiency syndrome

Major abdominal surgery

Intestinal dysmotility

Hirschsprung's disease

Chronic idiopathic intestinal pseudo-obstruction syndrome

Gastroschisis

Disorders of the intestinal mucosa

Short-bowel syndrome

Absence of ileocecal valve

which is an important cause of morbidity and mortality in children with IF (8). Experimentally induced SIBO in rats leads to the appearance of gut bacteria in the mesenteric lymph nodes (MLNs) and visceral organs $(9,10)$. Using DNA fingerprinting, Reddy et al (11) confirmed that Escherichia coli isolates from the MLNs of surgical patients were identical to the fecal samples obtained from within the lumen of resected colostomy specimens immediately after removal, thus confirming the gut origin of translocated bacteria.

The limitations of currently available tests and, consequently, the lack of an established criterion for accurate diagnosis of SIBO, continue to challenge physicians managing children with IF. Therefore, empirical antibiotics are often used to treat presumed SIBO in this population to reduce bacterial counts. To date, large, controlled, clinical trials aimed at establishing diagnostic techniques and ascertaining the efficacy of antibiotics against SIBO in pediatric IF patients have not been reported. The present article provides an overview of the current understanding in detection and proposes potential management strategies for SIBO in pediatric IF.

\section{DIAGNOSTIC TOOLS FOR PEDIATRIC SIBO}

Culture of direct aspirates of small bowel contents, and hydrogen breath testing (HBT) are techniques used in the diagnosis of SIBO. These techniques vary in sensitivity and specificity, and are susceptible to false-positive or false-negative interpretations. Although there is evidence supporting the utility of breath tests for SIBO diagnosis in adults and older children, they are not reliable in young IF patients due to inadequate breath collection and rapid gut transit, especially in patients with short bowel syndrome, thus giving rise to false-positive results (12). Serum levels of folate and vitamin $B_{12}$ may be used in conjunction with the aforementioned techniques to support evidence of bacterial overgrowth. The rationale for this test is that exogenous sources such as diet are relied on for maintaining adequate folate levels; however, synthesis of folate by intestinal microflora also contributes to the host's folate level (13). Therefore, serum folate levels may increase while vitamin $B_{12}$ levels decrease as a result of SIBO; however, measuring vitamin $\mathrm{B}_{12}$ and folate levels were found to have a poor diagnostic yield (14).

Due to the difficulty in diagnosing SIBO, emerging molecular techniques in bacterial 'fingerprinting' such as the use of

\section{BOX 1}

Limitations of diagnostic tests

- Major limitations of direct aspirate culture

- Reflects only a single site of the gut; however, bacterial overgrowth may be patchy (ie, samples may not be representative of the entire intestine, thus compromising reproducibility).

- Increased potential of contamination by oropharyngeal bacteria during intubation.

- Not all bacteria are easy to culture; longer incubation periods and specialized chamber conditions may be required. Of the 500 to 1000 identified species, less than $20 \%$ can be grown in laboratory (18).

- Reproducibility of small bowel aspiration and culture is low compared with hydrogen breath testing $(18,50)$.

- Invasive, especially for patients who require repeated testing.

- Lack of standardization of diagnostic test protocol (intra- and interindividual variations impose significant limitations on developing protocols to increase sensitivity and specificity for detecting bacterial overgrowth).

- Labour intensive and expensive.

- Centres may lack the appropriate equipment and laboratory support for proper collection and analysis.

- Major limitations of hydrogen breath testing

- Requires the presence of an active bacteria flora capable of metabolizing carbohydrate to hydrogen.

- Breath excretion of intestinally derived gases reflects only net excretion and does not account for metabolic consumption of hydrogen by the lumen.

- Test is inaccurate when pediatric patients cannot breathe into the collecting devices. Ineffective for patients with respiratory distress.

- Prolonged testing required for patients with slow small intestinal transit time.

- Need for cut-off values for age-, sex- and disease-matched controls (most pediatric procedures are an extension of adult studies; the diagnostic values may be misrepresented).

- Specificity can be compromised by excessive substrate dosage, leading to osmotic fluid shifts, shortened transit time and, subsequently, a faster delivery of substrate to the colon (26).

- Specialized equipment and trained technicians required.

- Major limitations of polymerase chain reaction-denaturing gradient gel electrophoresis

- Single population may have multiple ribosomal RNA operons with different 16S ribosomal RNA gene sequence.

- DNA purification required for polymerase chain reaction detection of bacteria in feces (ie, feces contain bilirubin and bile salts, which can interfere with polymerase chain reaction analysis) (51).

polymerase chain reaction denaturing gradient gel electrophoresis (PCR-DGGE) and bacterial 16S-ribosomal DNA sequencing may offer a more reliable way to define microbial populations in intestinal samples.

Direct aspiration and culture of small bowel contents Upper small bowel aspirate is collected during gastrointestinal endoscopy or via nasojejunal tube insertion with a sterile catheter. The collection of upper small bowel aspirate is rarely performed in pediatric patients because it is time consuming and often requires the use of general anesthetic (15). For culture and isolation, the samples are diluted and plated on aerobicand anaerobic-specific enriched agar plate media, with the actual numbers of bacteria determined by serial dilutions and counting CFUs (16). Box 1 describes the major concerns with direct aspirate culture: intubation is a high-risk invasive 
procedure, and bacterial cultures are limited to identifying only a minority of microbes that inhabit the intestine (17).

\section{HBT}

Abnormal production of gaseous byproducts of bacterial fermentation is a hallmark of SIBO (18). HBT is a noninvasive, indirect diagnostic method that relies on the ability of intestinal bacteria to metabolize carbohydrate moieties (eg, glucose, lactulose and xylose) that release hydrogen, methane and/or carbon dioxide in measureable levels from exhaled air (19). Humans do not exhale hydrogen when fasting or at rest because anaerobic metabolism does not occur in these two states (20). If measureable hydrogen is excreted with the exhaled air, it is presumed to have originated from the metabolism of nonabsorbed carbohydrate by anaerobic bacteria. Therefore, the exhaled hydrogen indicates the quantity and metabolic activity of anaerobic bacteria in the intestine, which is expressed in parts per million (21). The mechanism and interpretation of HBT have been previously discussed (18,21-25). In most centres, lactulose and glucose are commonly used as substrates for HBT. Carbon dioxide breath tests using either carbon-13 or carbon-14 xylose as substrates are less commonly employed. These breath tests are difficult to administer in pediatric IF patients due to rapid intestinal transit time, the difficulty with breath collection and the interpretation of results (26). The main clinical concerns of the breath testing modality is the high degree of false-positive and false-negative results despite preventive measures such as oral hygiene and the avoidance of specific foods to minimize their effect on hydrogen production (19). Measuring both hydrogen and methane levels may be required in some cases because not all colonizing bacteria are capable of metabolizing carbohydrates to hydrogen. An estimated $27 \%$ of individuals are 'nonhydrogen producers', resulting in false-negative results if the measurement is restricted to hydrogen (27). Conditions of impaired digestion and absorption of carbohydrates in the small intestine, and rapid transit time lead to abnormal HBT results when dietary sugars such as glucose are used for testing because glucose is metabolized to hydrogen by colonic bacteria (7). Another concern is that respiratory symptoms, such as higher respiratory rate, can make breath collection inadequate for diagnosis. Hyperventilation induced by crying or stress can also lead to false-negative results. The limitations of HBT reduce the reliability and applicability of the results to individual patients with intrinsic gastrointestinal problems such as IF.

\section{Molecular 'fingerprinting' of bacterial populations}

Introduced in the early 1980s, DNA fingerprinting remains a developing area of interest for clinical use. PCR-DGGE fingerprinting is one example of these advanced molecular techniques that can be used as novel strategies for the detection of microbes in the gastrointestinal tract of IF patients with suspected SIBO. It is a versatile technique that can be applied to different samples obtained noninvasively (eg, fecal mass) or through invasive methods (eg, small intestinal aspirate, MLN or tissue samples obtained from biopsy). PCR using universal bacterial 16S ribosomal RNA primers enables rapid, comprehensive quantitative and qualitative information, as well as specific detection of a wide range of bacterial species (28). The dominant bacterial population in the sample is identified using

\section{TABLE 2}

Oral antibiotics used (approximately seven to 10 days) to treat small intestinal bacterial overgrowth

\begin{tabular}{ll}
\hline Antibiotic & Dose \\
\hline Trimethoprim/sulfamethoxazole & $2-10 \mathrm{mg} / \mathrm{kg} / \mathrm{dose}$ bid \\
Metronidazole & $10 \mathrm{mg} / \mathrm{kg} / \mathrm{dose}$ bid \\
Broad-spectrum antibiotics & \\
Amoxicillin-clavulanic acid & $15 \mathrm{mg} / \mathrm{kg} / \mathrm{dose}$ bid \\
Rifaximin & $10-15 \mathrm{mg} / \mathrm{kg} / \mathrm{dose}$ bid \\
*Tetracycline & $10-15 \mathrm{mg} / \mathrm{kg} / \mathrm{dose}$ tid \\
Fluoroquinolones & \\
Ciprofloxacin & $10-20 \mathrm{mg} / \mathrm{kg} / \mathrm{dose}$ bid \\
Aminoglycoside antibiotics & \\
Gentamicin & $5 \mathrm{mg} / \mathrm{kg} / \mathrm{dose}$ bid \\
Neomycin & $2.5 \mathrm{mg} / \mathrm{kg} / \mathrm{dose}$ qid \\
\hline
\end{tabular}

*Recommended for children older than eight years of age. bid Twice per day; qid Four times per day; tid Three times per day. Data from reference 52

densitometry. Knowing the bacterial profile of the identified SIBO patient can direct the use of target-specific antibiotic therapy. The PCR-DGGE method has been evaluated $(11,28-30)$. PCR is regarded to be a superior technique over standard culture because it can detect unculturable or dead bacterial cells in situ (25).

\section{Management}

Bacterial overgrowth often recurs, and requires prolonged treatment including sporadic or periodic antibiotic therapy. During treatment of IF patients, the risks of long-term antibiotic therapy, intolerance, extent of systemic absorption and bacterial resistance must also be considered (8). Proton pump inhibitors, $\mathrm{H}_{2}$-receptor antagonists and antidiarrheals should be used with caution because decreased gastric acidity and motility may promote SIBO. Effective medical management and the correction of nutritional deficiencies reduce severity, and could prevent recurrent bacterial overgrowth. The bacterial species involved in inducing SIBO are diverse; preference is given to antibiotics effective against Gram-negative and anaerobic bacteria. Table 2 lists the antibiotics commonly used for treating SIBO described in the literature including controlled clinical trials, comparison studies and clinical reviews (8,31-41). At our institution, empirical treatment for moderate-risk patients (defined as those with no radiological or clinical evidence of dysmotility) comprises a seven-day treatment of rotating oral gentamicin and metronidazole, followed by no antibiotics for seven days and then restarting the cycle again (Figure 1A). Antibiotic cycling for high-risk patients (defined as radiological evidence of dysmotility, such as dilated bowel and/or clinical evidence of dysmotility such as gastrochisis) is comprised of cycling oral gentamicin and metronidazole for seven days each (Figure 1B). If high-risk patients experience recurrent sepsis, line infection or worsening cholestasis, antibiotic cycling of oral gentamicin and metronidazole followed by amoxicillin-clavulanic acid is recommended for seven days each (Figure 1C). In cases for which a duodenal aspiration is possible, a tailored antibiotic regimen according to sensitivity is considered. The efficacy of the three antibiotic cycling regimens has yet to be clinically validated and is, therefore, offered herein as an expert opinion only. Gentamicin is an aminoglycoside associated with very poor enteral absorption and minimal side effects, and is administered to pediatric IF patients harbouring an overgrowth of 


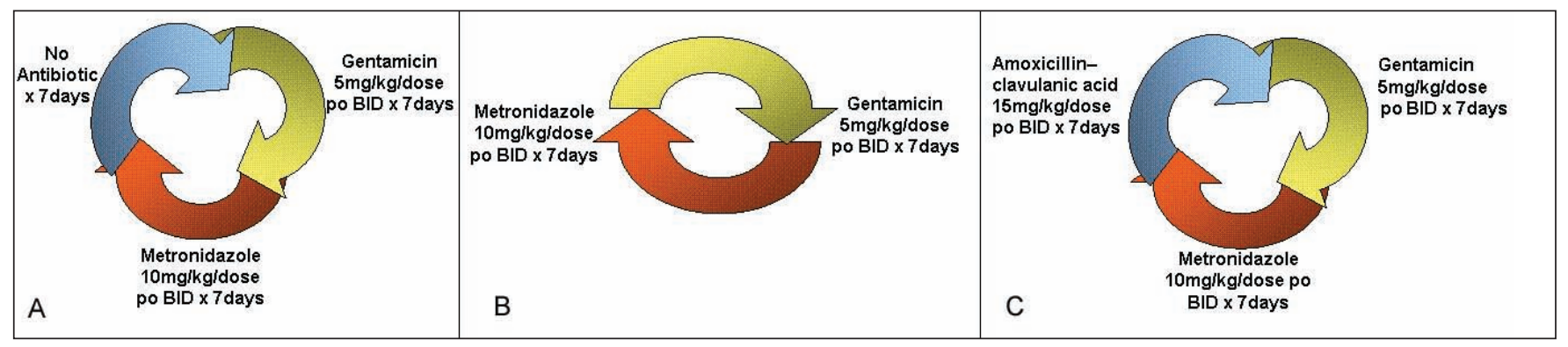

Figure 1) A Antibiotic cycling for moderate-risk bacterial overgrowth. B Antibiotic cycling for high-risk bacterial overgrowth. C Antibiotic cycling for high-risk recurrent sepsis, line infection and worsening cholestasis accompanying severe bacterial overgrowth. BID Twice per day; po Orally

Gram-negative organisms (12,42). Bartlett et al (43) conducted a randomized, double-blind, placebo-controlled clinical trial of oral gentamicin (10 mg/kg body weight/day for five days) in 45 children with persistent diarrhea (placebo $n=47$ ). A significant difference between treatment groups was not identified and serum trough gentamicin levels were not measurable (43). We commonly prescribe an oral dose of $10 \mathrm{mg} / \mathrm{kg} /$ day and believe this is effective and safe. In our clinical practice, serum trough gentamicin levels have always been either undetectable or less than the therapeutic range in routine monitoring. In animal models (44), gentamicin was found to improve small intestinal motility and transit rate in rats with SIBO. The study also reported that oral treatment with gentamicin lowered serum alanine aminotransferase, aspartate aminotransferase and tumour necrosis factor-alpha levels, indicating a reduction in the severity of nonalcoholic steatohepatitis in rats. Nitromidazoles are active against anaerobic bacteria, with limited activity against aerobes (45). Human and animal models (46) demonstrated the prevention of and protection against hepatic injury following metronidazole treatment for SIBO. Bouhnik et al (47) reported that amoxicillin-clavulanic acid is a suitable candidate for treating SIBO. Amoxicillin-clavulanic acid was effective against more than $90 \%$ of bacterial strains, thus supporting its use as first-line therapy (47). In a randomized crossover study, Attar et al (31) compared the efficacy of antibiotics (norfloxacin, $800 \mathrm{mg} /$ day; amoxicillin-clavulanic acid, $1500 \mathrm{mg} /$ day) and probiotic (Saccharomyces boulardii $1500 \mathrm{mg} /$ day) in 10 adults with bacterial overgrowth-related diarrhea. Each patient underwent five seven-day treatment periods; amoxicillin-clavulanic acid and norfloxacin reduced the number of stools and improved HBT results. Antibiotics for SIBO management are summarized in Table 2. Most of these antibiotic studies were performed in adults; unfortunately, there are very

\section{REFERENCES}

1. Vanner $\mathrm{S}$. The small intestinal bacterial overgrowth. Irritable bowel syndrome hypothesis: Implications for treatment. Gut 2008;57:1315-21.

2. Rana SV, Bhardwaj SB. Small intestinal bacterial overgrowth. Scand J Gastroenterol 2008;43:1030-7.

3. Carter BA, Karpen SJ. Intestinal failure-associated liver disease: Management and treatment strategies past, present, and future. Semin Liver Dis 2007;27:251-8.

4. Vanderhoof JA, Young RJ, Thompson JS. New and emerging therapies for short bowel syndrome in children. Paediatr Drugs 2003;5:525-31.

5. Goulet O, Ruemmele F. Causes and management of intestinal failure in children. Gastroenterology 2006;130(2 Suppl 1):S16-28.

6. Guglielmi FW, Regano N, Mazzuoli S, et al. Cholestasis induced by total parenteral nutrition. Clin Liver Dis 2008;12:97-110. few published interventional studies that assessed the effectiveness of prophylaxis and therapy in pediatric SIBO patients with IF. Probiotic use for SIBO in children with IF has been reported; however, the safety and efficacy of this treatment in this particular population needs further study, especially for the risk of probiotic bacteremia and catheter-related sepsis $(8,48)$.

\section{CONCLUSION}

With substantial improvements in the surgical and medical approaches to the management of pediatric gastrointestinal pathologies, the frequency of children diagnosed with IF is increasing. Reduced antegrade peristalsis combined with impaired mucosal immunity creates an optimal environment for bacterial colonization and subsequent overgrowth (49). Bacterial translocation is a potential complication of SIBO; therefore, early diagnosis and management, and prevention of recurrent SIBO is extremely important. Although many diagnostic techniques have been introduced over the years, each test has limitations in identifying patients with SIBO. Establishing a gold standard diagnostic test for SIBO in children requires further investigation. The application of emerging molecular techniques in profiling bacterial populations in the gastrointestinal tract is promising in the study of SIBO. Monitoring and managing SIBO in IF patients is crucial and challenging. For cases in which a firm diagnosis cannot be made, but clinical symptoms favour SIBO, empirical antibiotic use may be a more cautious approach to prevent delay of treatment and to prevent increases in symptom severity. The efficacy of antibiotic cycling in SIBO must be clinically investigated in the pediatric IF population. Close monitoring and early detection of infection, and aggressive prevention of bacterial overgrowth, will likely improve prognosis.

7. Quigley EM, Quera R, Abu-Shanab A, eds. The Enteric Flora in Intestinal Failure: Small Intestinal Bacterial Overgrowth and Gut-Derived Sepsis. Malden: Blackwell Publishing, 2008.

8. Quigley EM, Quera R. Small intestinal bacterial overgrowth: Roles of antibiotics, prebiotics, and probiotics. Gastroenterology 2006;130(2 Suppl 1):S78-90.

9. Teo M, Chung S, Chitti L, et al. Small bowel bacterial overgrowth is a common cause of chronic diarrhea. J Gastroenterol Hepatol 2004;19:904-9.

10. Nieuwenhuijs VB, van Dijk JE, Gooszen HG, Akkermans LM. Obstructive jaundice, bacterial translocation and interdigestive small-bowel motility in rats. Digestion 2000;62:255-61.

11. Reddy BS, MacFie J, Gatt M, Macfarlane-Smith L, Bitzopoulou K, Snelling AM. Commensal bacteria do translocate across the intestinal barrier in surgical patients. Clin Nutr 2007;26:208-15. 
12. Malone FR, Horslen SP. Medical and surgical management of the paediatric patient with intestinal failure. Curr Treat Options Gastroenterol 2007;10:379-90.

13. Camilo E, Zimmerman J, Mason JB, et al. Folate synthesized by bacteria in the human upper small intestine is assimilated by the host. Gastroenterology 1996;110:991-8.

14. Suter PM, Golner BB, Goldin BR, Morrow FD, Russell RM. Reversal of protein-bound vitamin B12 malabsorption with antibiotics in atrophic gastritis. Gastroenterology 1991;101:1039-45.

15. Lewis SJ, Young G, Mann M, Franco S, O'Keefe SJ. Improvement in specificity of [14C] d-xylose breath test for bacterial overgrowth. Dig Dis Sci 1997;42:1587-92.

16. Ghoshal U, Ghoshal UC, Ranjan P, Naik SR, Ayyagari A. Spectrum and antibiotic sensitivity of bacteria contaminating the upper gut in patients with malabsorption syndrome from the tropics. BMC Gastroenterol 2003;24;3:9.

17. Eckburg PB, Bik EM, Bernstein CN, et al. Diversity of the human intestinal microbial flora. Science 2005;308:1635-8.

18. Van Citters GW, Lin HC. Management of small intestinal bacterial overgrowth. Curr Gastroenterol Rep 2005;7:317-20.

19. Saad RJ, Chey WD. Breath tests for gastrointestinal disease: The real deal or just a lot of hot air? Gastroenterology 2007;133:1763-6.

20. Levitt MD. Production and excretion of hydrogen gas in man. N Engl J Med 1969;281:122-7.

21. Eisenmann A, Amann A, Said M, Datta B, Ledochowski M. Implementation and interpretation of hydrogen breath tests. J Breath Res 2008;2:1-9.

22. Vanner S. The lactulose breath test for diagnosing SIBO in IBS patients: Another nail in the coffin. Am J Gastroenterol 2008;103:964-5.

23. Nucera G, Gabrielli M, Lupascu A, et al. Abnormal breath tests to lactose, fructose and sorbitol in irritable bowel syndrome may be explained by small intestinal bacterial overgrowth. Aliment Pharmacol Ther 2005;21:1391-5.

24. Anania C, Pacifico L, Olivero G, Osborn JF, Bonaiuto E, Chiesa C. Breath tests in paediatrics. Clin Chim Acta 2008;397:1-12.

25. Gasbarrini A, Corazza GR, Gasbarrini G, et al. Methodology and indications of $\mathrm{H}_{2}$-breath testing in gastrointestinal diseases: The Rome Consensus Conference. Aliment Pharmacol Ther 2009;29(Suppl 1):1-49.

26. Bishop WP. Breath hydrogen testing for small bowel bacterial overgrowth - a lot of hot air? J Pediatr Gastroenterol Nutr 1997;25:245-6

27. Dibaise JK, Young RJ, Vanderhoof JA. Enteric microbial flora, bacterial overgrowth, and short-bowel syndrome. Clin Gastroenterol Hepatol 2006;4:11-20.

28. Wang RF, Cao WW, Cerniglia CE. PCR detection and quantitation of predominant anaerobic bacteria in human and animal fecal samples. Appl Environ Microbiol 1996;62:1242-7.

29. Hayashi H, Sakamoto M, Benno Y. Phylogenetic analysis of the human gut microbiota using 16S rDNA clone libraries and strictly anaerobic culture-based methods. Microbiol Immunol 2002;46:535-48

30. Walter J, Hertel C, Tannock GW, Lis CM, Munro K, Hammes WP. Detection of Lactobacillus, Pediococcus, Leuconostoc, and Weissella species in human feces by using group-specific PCR primers and denaturing gradient gel electrophoresis. Appl Environ Microbiol 2001;67:2578-85.

31. Attar A, Flourie B, Rambaud JC, Franchisseur C, Ruszniewski P, Bouhnik Y. Antibiotic efficacy in small intestinal bacterial overgrowth-related chronic diarrhea: A crossover, randomized trial. Gastroenterology 1999;117:794-7.

32. Castiglione F, Rispo A, Di Girolamo E, et al. Antibiotic treatment of small bowel bacterial overgrowth in patients with Crohn's disease. Aliment Pharmacol Ther 2003;18:1107-12.
33. Church DL, Bryant RD, Sim V, Laishley EJ.

Metronidazole susceptibility and the presence of hydrogenase in pathogenic bacteria. Anaerobe 1996;2:147-53.

34. Di Stefano M, Malservisi S, Veneto G, Ferrieri A, Corazza GR. Rifaximin versus chlortetracycline in the short-term treatment of small intestinal bacterial overgrowth. Aliment Pharmacol Ther 2000;14:551-6.

35. Di Stefano M, Miceli E, Missanelli A, Mazzocchi S, Corazza GR. Absorbable vs. non-absorbable antibiotics in the treatment of small intestine bacterial overgrowth in patients with blind-loop syndrome. Aliment Pharmacol Ther 2005;21:985-92.

36. Lauritano EC, Gabrielli M, Lupascu A, et al. Rifaximin dose-finding study for the treatment of small intestinal bacterial overgrowth. Aliment Pharmacol Ther 2005;22:31-5.

37. Majewski M, Reddymasu SC, Sostarich S, Foran P, McCallum RW. Efficacy of rifaximin, a nonabsorbed oral antibiotic, in the treatment of small intestinal bacterial overgrowth. Am J Med Sci 2007;333:266-70.

38. Pimentel M. Review of rifaximin as treatment for SIBO and IBS. Expert Opin Investig Drugs 2009;18:349-58.

39. Scarpellini E, Gabrielli M, Lauritano CE, et al. High dosage rifaximin for the treatment of small intestinal bacterial overgrowth. Aliment Pharmacol Ther 2007;25:781-6.

40. Vanderhoof JA, Young RJ, Murray N, Kaufman SS. Treatment strategies for small bowel bacterial overgrowth in short bowel syndrome. J Pediatr Gastroenterol Nutr 1998;27:155-60.

41. Yang J, Lee HR, Low K, Chatterjee S, Pimentel M. Rifaximin versus other antibiotics in the primary treatment and retreatment of bacterial overgrowth in IBS. Dig Dis Sci 2008;53:169-74.

42. Weinstein MJ, Wagman GH, Oden EM, Marquez JA. Biological activity of the antibiotic components of the gentamicin complex. J Bacteriol 1967;94:789-90.

43. Bartlett AV, Torun B, Morales C, Cano F, Cruz JR. Oral gentamicin is not effective treatment for persistent diarrhea. Acta Paediatr Suppl 1992;381:149-54.

44. Wu WC, Zhao W, Li S. Small intestinal bacteria overgrowth decreases small intestinal motility in the NASH rats. World J Gastroenterol 2008;14:313-7.

45. Church DL, Laishley EJ. Reduction of metronidazole by hydrogenase from Clostridia. Anaerobe 1995;1:81-92.

46. Capron JP, Gineston JL, Herve MA, Braillon A. Metronidazole in prevention of cholestasis associated with total parenteral nutrition. Lancet 1983;1:446-7.

47. Bouhnik Y, Alain S, Attar A, et al. Bacterial populations contaminating the upper gut in patients with small intestinal bacterial overgrowth syndrome. Am J Gastroenterol 1999;94:1327-31.

48. Land MH, Rouster-Stevens K, Woods CR, Cannon ML, Cnota J, Shetty AK. Lactobacillus sepsis associated with probiotic therapy. Paediatrics 2005;115:178-81.

49. Soondrum K, Hinds R. Management of intestinal failure. Indian J Pediatr 2006;73:913-8.

50. Tillman R, King C, Toskes P. Continued experience with the xylose breath test: Evidence that the small bowel culture as the gold standard for bacterial overgrowth may be tarnished. Gastroenterology 1981;80:A1304 (Abst).

51. Wilde J, Eiden J, Yolken R. Removal of inhibitory substances from human fecal specimens for detection of group A rotaviruses by reverse transcriptase and polymerase chain reactions. J Clin Microbiol 1990;28:1300-7.

52. Ching YA, Gura K, Modi B, Jaksic T. Paediatric intestinal failure: Nutrition, pharmacologic, and surgical approaches. Nutr Clin Pract 2007;22:653-63. 


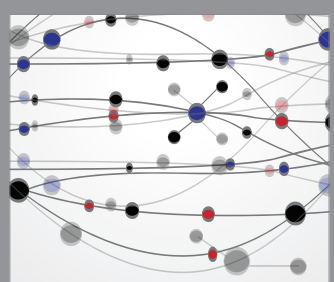

The Scientific World Journal
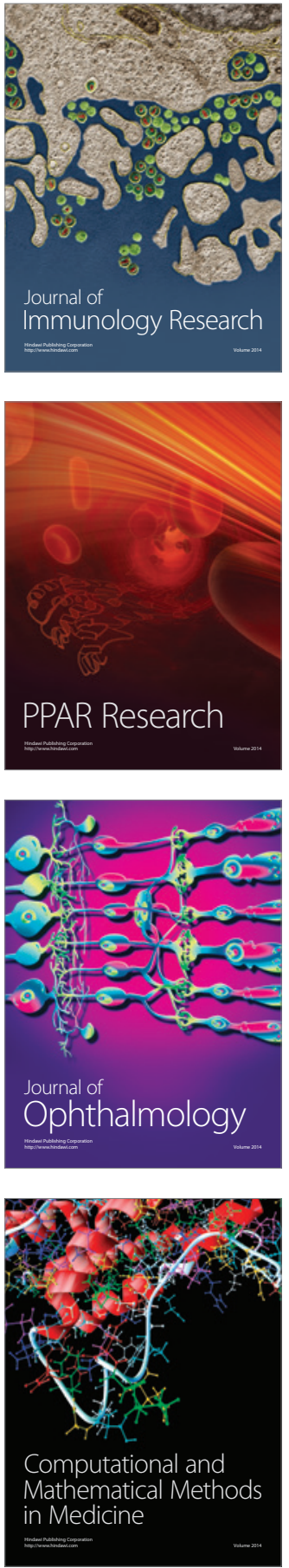

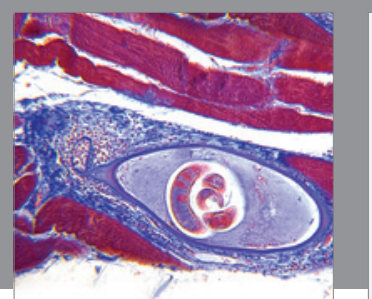

Gastroenterology Research and Practice

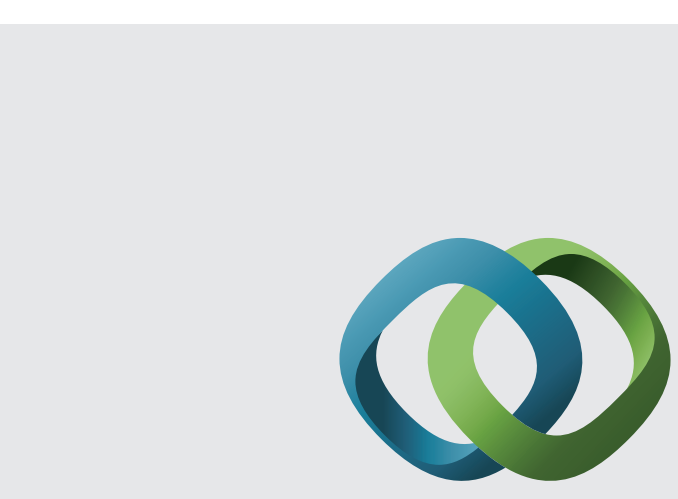

\section{Hindawi}

Submit your manuscripts at

http://www.hindawi.com
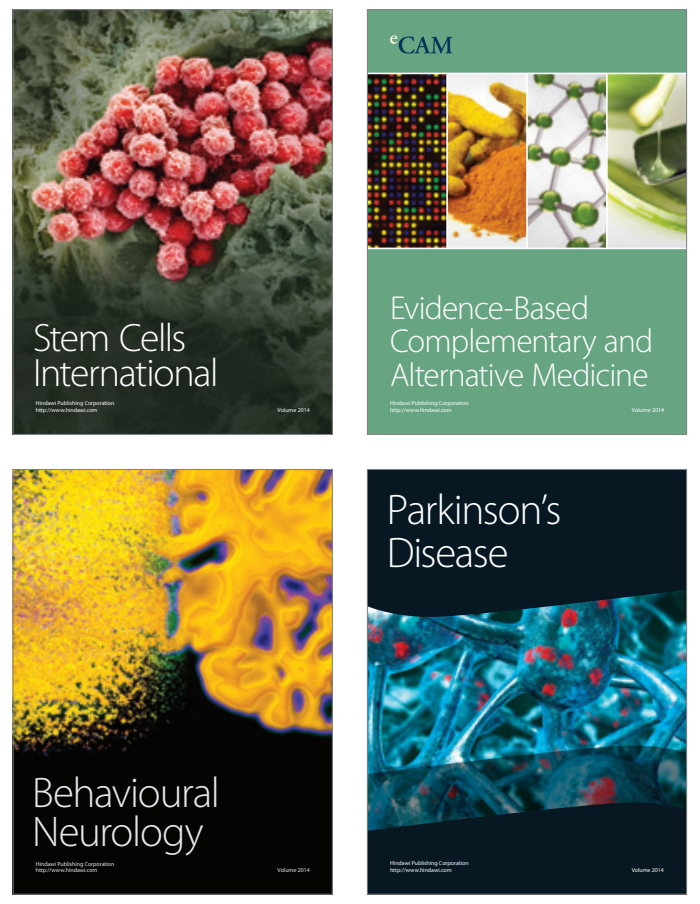
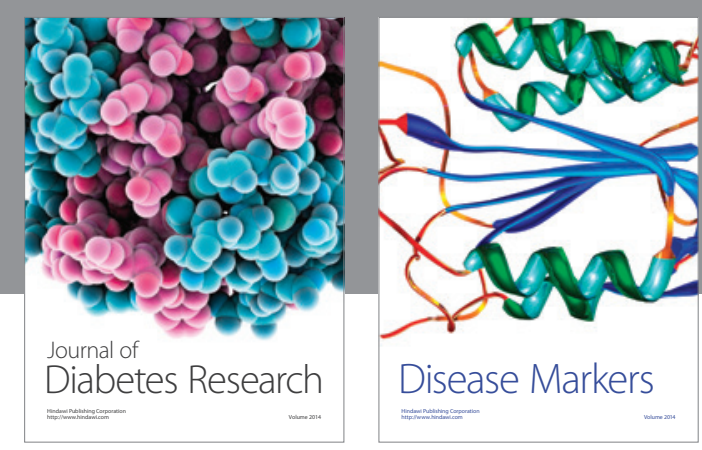

Disease Markers
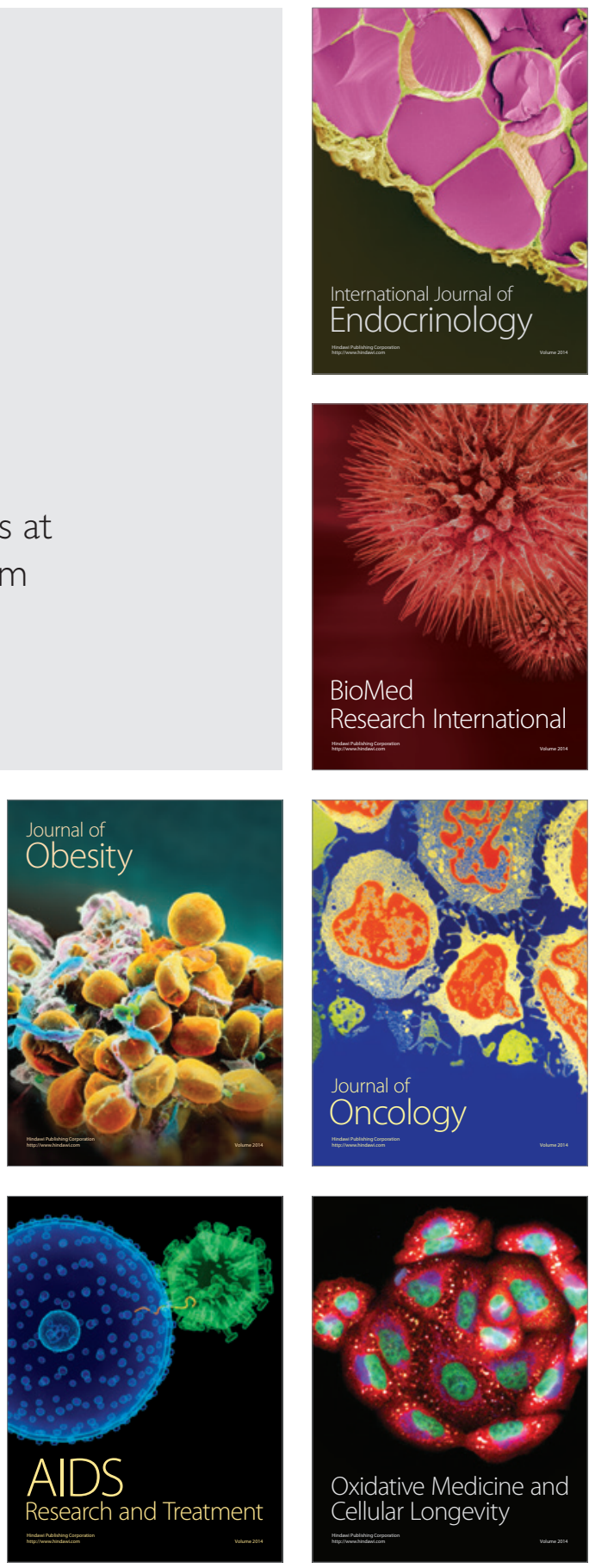